\section{Commentary: Aortic root endocarditis: Frozen solutions or free to style yourself}

\author{
Lawrence M. Wei, MD, Chris C. Cook, MD, and \\ Harold G. Roberts, MD
}

In this issue of the Journal, Yang and colleagues ${ }^{1}$ report their institutional series of 336 patients with aortic valve endocarditis treated surgically from 1996 to 2017, specifically focusing on the impact of aortic root abscess on perioperative outcomes and long-term survival. The perioperative mortality in the abscess group (8.4\%) was higher than in the nonabscess group $(3.8 \%)$, but the difference was not significant $(P=.11)$ and was commendably low compared with other series. ${ }^{2,3}$ Ten-year survival did not differ between abscess $(41 \%)$ and nonabscess $(43 \%)$ groups nor did the 10 -year reoperation rate. Although some have advocated using homografts to treat aortic root abscess, ${ }^{4-6}$ the authors preferred to implant stentless bioprostheses because of concerns about homograft calcification, availability, and expense. In nonabscess cases, they used stented prostheses $(44.5 \%)$, mechanical valves $(9 \%)$, and root replacements $(46.5 \%)$, and in abscess cases they used mostly root replacements (both total root and inclusion techniques) with stentless bioprostheses. Their excellent results are a testament to their skill with these complex procedures and support their contention that stentless roots are a valid choice of conduit to treat endocarditis with root abscess.

Proponents of homografts for aortic root reconstruction endorse their relative resistance to recurrent infection and a greater versatility for reconstructing extensive defects of the aortic root and aorto-mitral continuity as primary

\footnotetext{
From the Department of Cardiovascular and Thoracic Surgery, West Virginia University, Morgantown, WVa.

Disclosures: The authors reported no conflicts of interest.

The Journal policy requires editors and reviewers to disclose conflicts of interest and to decline handling or reviewing manuscripts for which they may have a conflict of interest. The editors and reviewers of this article have no conflicts of interest.

Received for publication April 3, 2020; revisions received April 3, 2020; accepted for publication April 3, 2020; available ahead of print April 18, 2020.

Address for reprints: Lawrence M. Wei, MD, Department of Cardiovascular and Thoracic Surgery, PO Box 8003, West Virginia University Heart and Vascular Institute, One Medical Center Drive, Morgantown, WV 26506 (E-mail: Lawrence. wei@wvumedicine.org).

J Thorac Cardiovasc Surg 2021;162:1060-1

$0022-5223 / \$ 36.00$

Copyright (c) 2020 by The American Association for Thoracic Surgery

https://doi.org/10.1016/j.jtcvs.2020.04.025
}

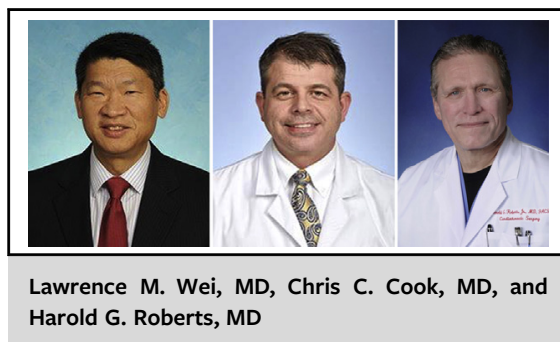

CENTRAL MESSAGE

Aortic root abscess may be

managed successfully with

extensive debridement and

reconstruction using various

techniques, including stentless

roots and homografts.

reasons to prefer this approach. ${ }^{6}$ The current study ${ }^{1}$ emphasizes the importance of extensive debridement while demonstrating that the resulting tissue defects may be reconstructed with stentless roots and pericardial patches with excellent survival and freedom from reoperation. Being from the geographic epicenter of the opioid epidemic, we routinely apply both homografts and stentless roots with pericardial reconstruction of the left ventricular outflow tract, with similar excellent results. As the incidence of endocarditis associated with intravenous drug use continues to grow, controlling the cost of therapy becomes more important and stentless valves may be favorable to homografts.

The authors perform a high percentage of aortic root replacement in patients without abscess with the goal of promoting better hemodynamics. Although their operative mortality is similar for valve replacement and root replacement, bypass and crossclamp times in the nonabscess group are relatively high, likely reflecting the higher complexity of a root replacement. Longer bypass times are associated with a greater incidence of coagulopathy and end-organ dysfunction. In a patient with endocarditis, or any higher-risk patient, a shorter operation may often be better. In the absence of root abscess, we prefer expeditious implantation of a stented bioprosthesis or mechanical prosthesis. When a more complex root replacement procedure is warranted, close attention to myocardial preservation is critical. We favor continuous antegrade perfusion via coronary ostial catheters whenever possible. 
The current study ${ }^{1}$ illustrates that good operative outcomes can be achieved in patients undergoing surgery for aortic root abscess in the setting of acute infective endocarditis. Operative mortality and long-term mortality are similar to those of patients without abscess. Applying careful surgical technique with an emphasis on complete debridement of infected tissue remains the key to success, regardless if one chooses a homograft or stentless prosthesis.

\section{References}

1. Yang B, Caceres J, Farhat L, Le T, Brown B, St. Pierre E, et al. Root abscess in the setting of infectious endocarditis: short- and long-term outcomes. J Thorac Cardiovasc Surg. 2021;162:1049-59.e1.
2. Leontyev S, Davierwala PM, Krögh G, Feder S, Oberbach A, Bakhtiary F, et al Early and late outcomes of complex aortic root surgery in patients with aortic root abscesses. Eur J Cardiothorac Surg. 2016;49:447-55.

3. Chen GJ, Lo WC, Tseng HW, Pan SC, Chen YS, Chang SC. Outcome of surgical intervention for aortic root abscess: a meta-analysis. Eur J Cardiothorac Surg. 2018;53:807-14.

4. Musci M, Weng Y, Hübler M, Amiri A, Pasic M, Kosky S, et al. Homograft aortic root replacement in native or prosthetic active infective endocarditis: twenty-year single-center experience. J Thorac Cardiovasc Surg. 2010;139:665-73.

5. Preventza O, Mohamed AS, Cooley DA, Rodriguez V, Bakaeen FG, Cornwell LD et al. Homograft use in reoperative aortic root and proximal aortic surgery for endocarditis: a 12-year experience in high-risk patients. J Thorac Cardiovasc Surg. 2014;148:989-94.

6. Sultan I, Bianco V, Kilic A, Chu D, Navid F, Gleason TG. Aortic root replacement with cryopreserved homograft for infective endocarditis in the modern North American opioid epidemic. J Thorac Cardiovasc Surg. 2019;157:45-50.
See Article page 1049.

\section{Commentary: Our short game is long but long game is short!}

\author{
Paul Stelzer, MD, and Ismail El-Hamamsy, MD
}

Infective endocarditis (IE) represents an important challenge at many levels. This is becoming all the more pressing with the opioid epidemic, which was declared a public health emergency in 2017. The study by Yang and colleagues ${ }^{1}$ specifically addresses the impact of aortic root abscesses in a cohort of 336 consecutive adults undergoing surgery for IE. The authors' main conclusion was that despite the added complexity and risk of perioperative complications in patients with aortic root abscesses, operative outcomes were favorable. The authors should be congratulated for their excellent results in a challenging patient population. Their results raise several important points.

First, this study highlights the well-established relationship between volumes and outcomes in cardiac surgery. Their operative results were excellent, which reinforces the importance of identifying centers of excellence in

\footnotetext{
From the Department of Cardiovascular Surgery, Icahn School of Medicine at Mount Sinai, New York, NY

Disclosures: Authors have nothing to disclose with regard to commercial support.

Received for publication March 25, 2020; revisions received March 25, 2020; accepted for publication March 26, 2020; available ahead of print April 9, 2020.

Address for reprints: Paul Stelzer, MD, Department of Cardiovascular Surgery, Icahn School of Medicine at Mount Sinai, 1190 Fifth Avenue, New York, NY 100296574 (E-mail: Paul.stelzer@mountsinai.org).

J Thorac Cardiovasc Surg 2021;162:1061-2

$0022-5223 / \$ 36.00$

Copyright (c) 2020 by The American Association for Thoracic Surgery

https://doi.org/10.1016/j.jtcvs.2020.03.092
}

\section{Check for updates}

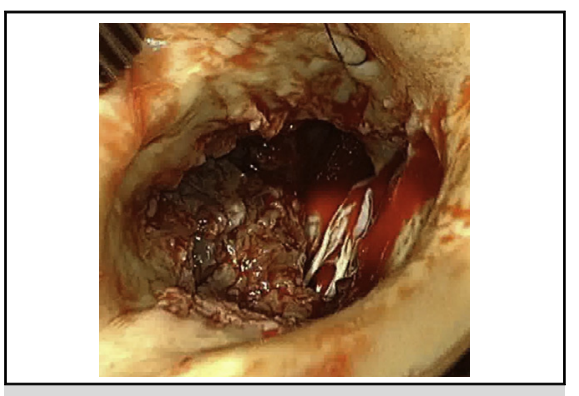

Extensive aortic root debridement requires complex reconstruction.

$$
\begin{aligned}
& \text { CENTRAL MESSAGE } \\
& \text { Complete debridement of } \\
& \text { infection + appropriate recon- } \\
& \text { struction by experienced aortic } \\
& \text { surgeons = good acute out- } \\
& \text { comes with or without root ab- } \\
& \text { scess but long-term survival is } \\
& \text { still suboptimal. }
\end{aligned}
$$

cardiac surgery to deal with greater-risk patients or greater-complexity interventions. Interestingly, however, although there was no difference in operative mortality from a statistical standpoint, there was a clinically relevant difference in mortality ( $>2$-fold) in patients with root abscesses $(8.4 \%$ vs $3.8 \%)$, underscoring the very real risk of severe root destruction. As the authors mention, the key principle is radical debridement of all infected tissue, followed by reconstruction. This can range from a simple patch with stented valve replacement to a full Commando 